\title{
The Impact of R\&D Expenditure upon the Efficiency of M\&A Deals with Hi-Tech Companies
}

\author{
Elena Ochirova
}

Research Assistant, Institute for Statistical Studies and Economics of Knowledge (ISSEK), eochirova@hse.ru

Yury Dranev

Leading Research Fellow, ISSEK, ydranev@hse.ru

National Research University Higher School of Economics, 11, Myasnitskaya str., Moscow 101000, Russian Federation

\begin{abstract}
$\mathrm{T}$ The motives behind merger and acquisitions (M\&A) are often linked to the opportunities to obtain knowledge and technologies in order to enhance the competitive advantages of companies. In particular, the acquisition of digital technologies through mergers and acquisitions with ICT companies is especially relevant. However, the efficiency of such deals is often low and calls

into question the implementation of digitalization strategies of companies. In this study we employ an approach for assessing the efficiency of M\&A deals with ICT companies by using the DEA method. Applying regression analysis, it was found that the high level of research and development expenses of the acquirers can negatively impact the efficiency of the M\&A deals with ICT companies.
\end{abstract}

Keywords: mergers and acquisitions (M\&A); ICT sector; research and development (R\&D); gross domestic expenditure on R\&D; DEA; digital technologies
Citation: Ochirova E., Dranev Yu. (2021) The Impact of R\&D Expenditure upon the Efficiency of M\&A Deals with Hi-Tech Companies. Foresight and STI Governance, 15(1), 31-38. DOI: $10.17323 / 2500-2597.2021 .1 .31 .38$ 
$\mathrm{I}$ nvesting in research and development (R\&D) can accelerate economic growth and improve business performance [Griliches, 1958, 1979; Mansfield, 1988; Hall, 1996; Koellinger, 2008]. A $10 \%$ increase in relevant domestic expenditures on average leads to a $1.6 \%$ increase in economic productivity [Bravo-Ortega, Marin, 2011]. One of the ways to accelerate companies' $R \& D$ and innovation development is through mergers and acquisitions (M\&A) intended to acquire necessary competencies to create and apply technological or other innovations [Hitt et al., 1991]. This strategy is seen as a long-term growth tool. Its choice is determined by the need to strengthen the research base and build up technological potential [Capron, Hulland, 1999; Haleblian et al., 2009, Sirmon et al., 2011].

Various aspects of the effect of "technological" mergers and acquisitions became the subject of empirical research. A number of studies (e.g. [Ahuja, Katila, 2001]) assess the impact of such deals upon the innovation or technological performance of buyer companies. Contrary to theoretical assumptions, empirical analysis not infrequently reveals the neutral [Prabhu et al., 2005] or negative [Ravenscraft, Scherer, 1987; Hitt et al., 1991, 1996] effect of M\&A deals on companies' innovative development. Possible factors include the following:

- the negative impact of companies' merger on the processes associated with $\mathrm{R} \& \mathrm{D}$ [Jemison, Haspeslagh, 1991; Ranft, Lord, 2002];

- loss of key employees during the transition period [Ernst, Vitt, 2000; Ranft, Lord, 2000];

- organizational imbalances and low technological compatibility between the involved parties [Chakrabarti et al., 1994; Hagedoorn, Duysters, 2002; Cloodt et al., 2006].

Technological consistency between the parties contributes to M\&A effectiveness [Cloodt et al., 2006]. The closer the parties' technological arsenals match one other, the easier it is for the buyer company to adapt and use the acquired assets [Cohen, Levinthal, 1990; Lane, Lubatkin, 1998]. In high-tech sectors including information and communication technologies (ICT), the development, creation, and application of new solutions involve a high level of uncertainty [Wagner, 2011]. M\&A strategies aimed at leveling the associated risks for the company are typically based on finding necessary technologies and knowledge externally [Desyllas, Hughes, 2008; Ortega-Argilés et al., 2010]. Acquiring a player with unique technological competencies helps to accelerate development by integrating new knowledge [Hitt et al., 1996]. In the age of digitization such strategies may be more effective than buying assets from other sectors of the economy.

The existing empirical studies on the effectiveness of "technological" M\&A deals mostly involve applying regression analysis to assess buyers' financial performance after the transaction has been completed [DeYoung et al., 2009]. Assessing how the company's technological indicators affect M\&A results requires eliminating the impact of various specific factors, which, given the limited functionality of regression techniques and a lack of data, is fraught with certain difficulties.

In our study the effects of M\&A are measured based on the basis input parameters of such deals with ICT companies using Data Envelopment Analysis (DEA).

The DEA technique, first presented in [Charnes et al., 1978], is widely applied as a way to measure the relative effectiveness of M\&A deals [Worthington, 2001; Bogetoft, Wang, 2005; Liu et al., 2007; Lozano, Villa, 2010; Peyrache, 2013; Wanke et al., 2017]. Compared to traditional performance metrics, it can take into account several input and output parameters to analyze non-linear functional dependencies between the data and is suitable for various sectors of the economy [Emrouznejad, Yang, 2018]. DEA allows one to proactively assess the impact of potential acquisition targets' various characteristics upon the buyer's capacities in the event the deal actually going through.

\section{Methodology of the Study}

We define ICT companies in line with the Bloomberg Industry Classification (BICS) which attributes companies to particular sectors on the basis of their main revenue-generating business segments [Phillips, Ormsby, 2016]. Our study covers segments such as semiconductors and semiconductor equipment; software and related services; communication services; and technological equipment. A number of parameters which describe the technological development of ICT companies whose activities depend on intangible assets (enabling them to develop, produce, and apply innovations) were considered. The motivation for M\&A is often assessed using models in which one of the objectives of merging businesses is to acquire intangible assets [Cassiman et al., 2005; Phillips, Zhdanov, 2013; Jovanovic, Rousseau, 2008]. Sectoral differences allow one to identify the effect of using such assets [Brown et al., 2009], in particular to measure their role in promoting companies' internal R\&D investments [Eisfeldt, Papanikolaou, 2014; Peters, Taylor, 2017].

Risk-avoiding firms in countries with low gross domestic expenditures on R\&D (GERD) tend to have a conservative attitude toward investing in $R \& D$, preferring more reliable strategies. In countries with a relatively low level of technological development, companies have to look for competencies they lack abroad [Belderbos et al., 2014]. Jurisdictions with a high level of GERD promote companies' innovation 
activities by offering knowledge flows, skilled labor, and opportunities to conduct R\&D jointly with other organizations [Iwasa, Odagiri, 2004; Griffith et al., 2006; Audretsch, Belitski, 2020]. At the same time companies in countries with a low level of GERD face information asymmetry combined with limited access to capital markets [Alam et al., 2019]. Thus, the level of GERD in a country becomes a factor determining the effectiveness of M\&A deals [Xie et al., 2017]. M\&A deals with ICT companies in jurisdictions with a relatively high value for this indicator are more likely to provide access to advanced technological knowledge and have a positive impact upon the buyer company. It should also be borne in mind that, as already noted, the level of technological development and innovation is industry-specific [Hagedoorn, Cloodt, 2003]. In high-tech sectors, R\&D expenditures are a key development driver [Duysters, Hagedoorn, 2001], so buyer companies are primarily interested in strengthening their own research potential with the acquired players' $\mathrm{R} \& \mathrm{D}$ results [Benou, Madura, 2005]. The resulting synergy increases the overall cost-effectiveness of $R \& D$ and helps the buyer company to grow. However, it is not at all easy to ensure that M\&A motivated by target companies' high $\mathrm{R} \& \mathrm{D}$ expenditures are feasible, since such investments are associated with a high degree of uncertainty. Furthermore, empirical research does not confirm that $\mathrm{R} \& \mathrm{D}$ expenditures always positively affect firms' overall performance [Chan et al., 2001; Hung et al., 2006]; sometimes a substitution effect is noted, when the R\&D carried out by the acquired company do not bring the expected benefits to the buyer [Hitt et al., 1991; Bloningen, Taylor, 2000; Cassiman et al., 2005].

Capital expenditures (CAPEX) serve as an indirect measure of companies' technological development [Healy et al., 1992], strengthening their performance and competitiveness by upgrading their technological assets [Andrade, Stafford, 2004]. Investment intensity is an indirect indicator of innovation activity [Stoneman, Kwon, 1996].
In our study the effects of "technological" M\&A are assessed using the DEA method taking into account input parameters describing the technological activities of target companies. Table 1 presents the variables used in our calculations: technological characteristics of the acquired firms in the year before the transaction, including $\mathrm{R} \& \mathrm{D}$ cost intensity, intangible assets, and capital investments. The ratio of companies' market and book values (which reflects their growth potential and attractiveness to investors) was also considered as an input variable. Two characteristics of buyer companies associated with changes in their value were used as output parameters, namely revenue growth and return on assets a year after the deal was completed [Kohers, Kohers, 2000].

The DEA model solves the maximization problem:

Output $_{i} /$ Input $_{i} \rightarrow \max =$ DEA $_{i}$ (1),

with

Output $_{i}<$ Input $_{i}$ and Output ${ }_{n}<$ Input $_{n}$

where:

Output $_{i}$ and Input $t_{i}$ are input and output variables for company $I$;

$n$ is the number of input and output variables.

To assess how the buyer company's R\&D and other indicators affect the deal results using the DEA method, a beta regression model was applied [Ferrari, Cribari-Neto, 2010]:

$$
\begin{gathered}
g\left(\mu_{i}\right)=\beta 0+\beta 1 R_{R} \& \operatorname{Dint}_{i, a}+\beta 2 \operatorname{Ln}\left(\text { Intangibles }_{i, a}\right)+ \\
\beta 3 \text { CAPEXint }_{i, a}+\beta 4 \operatorname{GERD}_{i, a}+\varepsilon_{i^{\prime}}
\end{gathered}
$$

where:

$R \& \operatorname{Dint}_{i, a}$, is R\&D expenditures-to-revenue ratio of the buyer company $i$ one year after the deal;

Ln(Intangibles $\left.{ }_{i, a}\right)$ is logarithm of intangible assets of the buyer company $i$ one year after the deal;

CAPEXint $_{i, a}$, is capital investments-to-revenue ratio of the buyer company $i$ one year after the deal;

\begin{tabular}{|c|c|}
\hline Variable & Variable description \\
\hline \multicolumn{2}{|r|}{ Input parameters (estimated values for target companies a year before the deal) } \\
\hline Ln(Intangibles $\left.{ }_{i, 1}\right)$ & Logarithm of the i-th company's intangible assets \\
\hline R\&Dint $_{i, t}$ & R\&D costs-to-revenue ratio of the i-th company \\
\hline CAPEXint $_{i, t}$ & Capital expenditures-to-revenue ratio of the i-th company \\
\hline$M t B_{i, t}$ & Market and book value ratio of the i-th company \\
\hline \multicolumn{2}{|r|}{ Output parameters (estimated values for buyer companies a year after the deal) } \\
\hline $\operatorname{Ln}(\text { RevGrowth })_{i, a}$ & Logarithm of the i-th company revenue growth \\
\hline$R O A_{i, a}$ & Return on i-th company's assets \\
\hline
\end{tabular}

Table 1. Input and Output Parameters 


\section{Table 2. Examples of M\&A Deals in the Technology Sector}

\begin{tabular}{|l|l|l|l|l|}
\hline \multicolumn{1}{|c|}{ Buyer company } & \multicolumn{1}{c|}{$\begin{array}{c}\text { Buyer company's home } \\
\text { country }\end{array}$} & \multicolumn{1}{|c|}{ Target company } & $\begin{array}{l}\text { Target company's home } \\
\text { country }\end{array}$ & \multicolumn{1}{c|}{ Deal date } \\
\hline Nokia Oyj & Finland & Alcatel Lucent SAS & France & 15.04 .2015 \\
\hline Diodes Inc & US & $\begin{array}{l}\text { BCD Semiconductor } \\
\text { Manufacturing Ltd }\end{array}$ & China & 26.12 .2012 \\
\hline Delta Electronics Inc & Taiwan & Eltek AS & Norway & 15.12 .2014 \\
\hline Informatica LLC & US & Heiler Software GmbH & Germany & 01.10 .2012 \\
\hline AT\&T Inc & US & Superclick Inc & Canada & 26.09 .2011 \\
\hline Schneider Electric SE & France & Telvent GIT SA & US & 01.06 .2011 \\
\hline Nuri Telecom Co Ltd & South Korea & Apivio Systems Inc & Canada & 17.01 .2017 \\
\hline Everbridge Inc & US & Unified Messaging Systems AS & Norway & 14.02 .2018 \\
\hline Source: composed by the authors. & & \\
\hline
\end{tabular}

$G E R D_{i, a}$, is GERD as share of GDP of the home country of the buyer company $i$ one year after the deal.

\section{Sample Description}

The sample of M\&A deals in the technology sector was based on the BICS index, meeting the following criteria:

- Date of the deal announcement: between January 1, 2010 to January 1, 2019.

- Deal status: completed, announced, pending completion.

- Target company belongs to at least one of the BICS technology sectors: Communication Services (10) (except the first-level micro-sector "Media and Entertainment") or Technology (18).

- Both companies (buyer and target) are public joint stock companies quoted on a stock exchange.

After applying these criteria, 322 deals were included in the sample (examples and descriptions are presented in Table 2).
Table 3. Descriptive Statistics of DEA Parameters and Beta Regression Determinants

\begin{tabular}{|c|c|c|c|}
\hline Variable & Average & $\begin{array}{l}\text { Standard } \\
\text { deviation }\end{array}$ & Median \\
\hline \multicolumn{4}{|c|}{ Input DEA parameters } \\
\hline$R \& \operatorname{Dint}_{i, t}$ & 0.1026 & 0.1303 & 0.0492 \\
\hline CAPEXint $_{i, t}$ & 0.0547 & 0.0951 & 0.0233 \\
\hline Ln(Intangibles $\left.{ }_{i, t}\right)$ & 0.2284 & 0.7647 & 0.0149 \\
\hline$M t B_{i, t}$ & 3.0072 & 14.4005 & 1.9241 \\
\hline \multicolumn{4}{|c|}{ Output DEA parameters } \\
\hline $\operatorname{Ln}(\text { RevGrowth })_{i, a}$ & 0.9573 & 4.2157 & 0.6357 \\
\hline$R O A_{i, a}$ & 2.3858 & 10.2538 & 3.8342 \\
\hline \multicolumn{4}{|c|}{ Independent beta regression variables } \\
\hline $\operatorname{R\mho Dint}_{i, a}$ & 0.1088 & 0.2466 & 0.0339 \\
\hline$G E R D_{i, a}$ & 2.3362 & 1.0495 & 2.7136 \\
\hline CAPEXint $_{i, a}$ & 0.0583 & 0.0705 & 0.0312 \\
\hline Ln(Intangibles $\left._{i, a}\right)$ & 0.9434 & 1.8086 & 0.5011 \\
\hline
\end{tabular}

\section{Figure 1. Distribution of DEA Estimates}

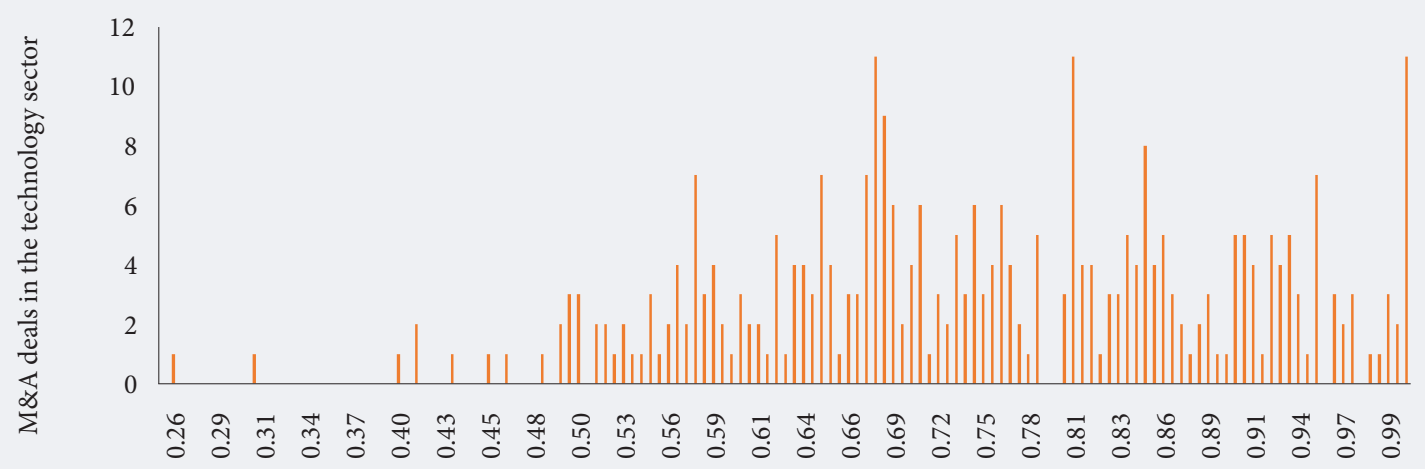

Source: composed by the authors.

DEA estimates 
Table 4. Beta Regression Results

\begin{tabular}{|l|r|r|r|r|}
\hline \multirow{2}{*}{$\begin{array}{c}\text { Dependent } \\
\text { variable }\end{array}$} & \multicolumn{4}{|c|}{ DEA estimates } \\
\cline { 2 - 5 } & Coefficients & $\begin{array}{c}\text { Standard } \\
\text { error }\end{array}$ & t-value & p-value \\
\hline Intercept & 1.6179 & 0.1851 & 8.741 & $0.000^{* * *}$ \\
\hline R\&Dint $_{i, a}$ & -0.7445 & 0.4525 & -1.645 & $0.100^{*}$ \\
\hline GERD $_{i, a}$ & -0.0942 & 0.0391 & -2.408 & $0.016^{* *}$ \\
\hline CAPEXint $_{i, a}$ & -3.4135 & 0.4393 & -7.769 & $0.000^{* * *}$ \\
\hline Ln(Intangibles $\left._{i, a}\right)$ & -0.0111 & 0.0186 & -0.596 & 0.551 \\
\hline Number of observations: 322 & \\
\hline $\begin{array}{l}\text { Note: } \text { This table shows the post-M\&A beta regression results. } \\
\text { denote significance at the } 10 \%, 5 \% \text { and } 1 \% \text { levels, respectively. }\end{array}$ \\
Source: composed by the authors. \\
\hline
\end{tabular}

The sample's descriptive statistics (Table 3) show that the target companies in M\&A deals tend to make relatively low investments in intangible assets compared to buyers. The share of intangible assets varies significantly between the deal parties. Their average R\&D cost intensity figures are similar, but the standard deviation is higher for buyers. The average GERDto-GDP ratio in buyer companies' home countries is relatively high, at about $2.3 \%$ of GDP.

\section{Results}

The DEA estimate distribution is shown in Figure 1. The values range from 0 to 1 , with relatively less effective deals in the sample located closer to 0 and relatively more effective ones closer to 1 .

To test R\&D expenditures' contribution to the relative effectiveness of M\&A, a beta regression analysis of buyer companies' technological characteristics was conducted. The results are presented in Table 4. Their significance is at $10 \%$.

High R\&D expenditures of buyer companies negatively affect M\&A results. A possible explanation is that firms which actively conduct R\&D on their own tend to use technologies obtained through mergers less effectively, while the knowledge acquired as a result of the deal replaces the existing one. The GERD-to-GDP ratio of the buyer's home country also negatively affects M\&A results. Therefore, the less technologically developed a country is, the more sense M\&A deals with ICT companies make for firms registered there.

The regression results (Table 4 ) indicate that target companies' intangible assets do not make a positive impact upon the buyer's relative productivity after the deal is concluded (the coefficient sign is in the negative, low value zone). This suggests that after an M\&A deal, buyers who invest a lot in intangible assets find it more difficult to efficiently handle the acquired company's technology. Finally, buyer companies' capital investment intensity is significant and negatively affects their post-M\&A performance.

\section{Conclusion}

Data Envelopment Analysis and a beta regression model were applied in this study to assess the effects of M\&A deals with ICT companies. The results show that the effectiveness of such transactions is negatively dependent upon the level of R\&D expenditures, by the buyer company and in its home country alike. This may be a consequence of the technology substitution effect [King et al., 2008] discovered in a number of studies in relation to ICT sector players. The effectiveness of applying digital technologies obtained from a target company depends upon the buyer's motivation to acquire new knowledge this way. There is a possibility that, if the buyer company actively conducts $\mathrm{R} \& \mathrm{D}$, the newly acquired technologies will turn out to be incompatible with its own unique developments. Accordingly, companies with a developed $\mathrm{R} \& \mathrm{D}$ base may have problems finding a player on the market acquiring whom would lead to a tangible increase in their competitiveness. The conclusions formulated in this paper can help not only with making investment decisions, but also with developing digitization strategies which involve acquiring technology and knowledge through the M\&A mechanism.

\section{References}

Ahuja G., Katila R. (2001) Technological acquisitions and the innovation performance of acquiring firms: A longitudinal study. Strategic Management Journal, 22, 197-220. https://doi.org/10.1002/smj.157

Alam A., Uddin M., Yazdifar H. (2019) Institutional determinants of R\&D investment: Evidence from emerging markets. Technological Forecasting and Social Change, 138, 34-44. https://doi.org/10.1016/j.techfore.2018.08.007

Andrade G., Stafford E. (2004) Investigating the economic role of mergers. Journal of Corporate Finance, 10 (1), 1-36. https:// doi.org/10.1016/S0929-1199(02)00023-8

Audretsch D.B., Belitski M. (2020) The role of R\&D and knowledge spillovers in innovation and productivity. European Economic Review, 123, 103391. https://doi.org/10.1016/j.euroecorev.2020.103391

Belderbos R., Cassiman B., Faems D., Leten B., Van Looy B. (2014) Co-ownership of intellectual property: Exploring the value-appropriation and value-creation implications of co-patenting with different partners. Research Policy, 43(5), 841852. https://doi.org/10.1016/j.respol.2013.08.013 
Benou G., Madura J. (2005) High-tech acquisitions, firm specific characteristics and the role of investment bank advisors. The Journal of High Technology Management Research, 16(1), 101-120. https://doi.org/10.1016/j.hitech.2005.06.006

Bloningen B.A., Taylor C.T. (2000) R\&D intensity and acquisitions in high technology industries: Evidence from the US electronic and electrical equipment industries. Journal of Industrial Economics, 68(1), 47-70. https://www.jstor.org/ stable/117483

Bogetoft P., Wang D. (2005) Estimating the Potential Gains from Mergers. Journal of Productivity Analysis, 23, $145-171$. https://doi.org/10.1007/s11123-005-1326-7

Bravo-Ortega C., Marin A.G. (2011) R\&D and Productivity: A Two Way Avenue? World Development, 39(7), $1090-1107$. https://doi.org/10.1016/j.worlddev.2010.11.006

Brown J.R., Fazzari S.M., Petersen B.C. (2009) Financing innovation and growth: Cash flow, external equity, and the 1990s R\&D boom. The Journal of Finance, 64(1), 151-185. https://doi.org/10.1111/j.1540-6261.2008.01431.x

Capron L., Hulland J. (1999) Redeployment of brands, sales forces, and general marketing management expertise following horizontal acquisitions: A resource-based view. Journal of Marketing, 63(2), 41-54. https://doi.org/10.1177\% 2F002224299906300203

Cassiman B., Colombo M.G., Garrone P., Veugelers R. (2005) The impact of M\&A on the R\&D process: An empirical analysis of the role of technological- and market-relatedness. Research Policy, 34(2), 195-220. https://doi.org/10.1016/j. respol.2005.01.002

Chakrabarti A., Hauschildt J. Süverkrüp C. (1994) Does it pay to acquire technological firms? R\&D Management, 24, $047-056$. https://doi.org/10.1111/j.1467-9310.1994.tb00846.x

Chan L., Lakonishok J., Sougiannis T. (2001) The Stock Market Valuation of Research \& Development Expenditures. Journal of Finance, 56(6), 2431-2456. https://doi.org/10.1111/0022-1082.00411

Charnes A., Cooper W.W., Rhodes E. (1978) Measuring the efficiency of decision making units. European Journal of Operational Research, 2, 429-444. https://doi.org/10.1016/0377-2217(78)90138-8

Cloodt M., Hagedoorn J., Kranenburg H.V. (2006) Mergers and acquisitions: Their effect on the innovative performance of companies in high-tech industries. Research Policy, 35(5), 642-654. https://doi.org/10.1016/j.respol.2006.02.007

Cohen W., Levinthal D. (1990) Absorptive Capacity: A New Perspective on Learning and Innovation. Administrative Science Quarterly, 35(1), 128-152. https://doi.org/10.2307/2393553

Desyllas P., Hughes A. (2008) Sourcing technological knowledge through corporate acquisition: Evidence from an international sample of high technology firms. The Journal of High Technology Management Research, 18(2), 157-172. https://doi. org/10.1016/j.hitech.2007.12.003

DeYoung R., Evanoff D.D., Molyneux P. (2009) Mergers and acquisitions of financial institutions: A review of the post-2000 literature. Journal of Financial Services Research, 36(2-3), 87-110. https://doi.org/10.1007/s10693-009-0066-7

Duysters G., Hagedoorn J. (2001) Do Company Strategies and Stuctures Converge in Global Markets? Evidence from the Computer Industry. Journal of International Business Studies, 32, 347-356. https://doi.org/10.1057/palgrave.jibs.8490956

Eisfeldt A.L., Papanikolaou D. (2014) The value and ownership of intangible capital. American Economic Review, 104 (5), 189-194. DOI: 10.1257/aer.104.5.189

Emrouznejad A., Yang G.L. (2018) A survey and analysis of the first 40 years of scholarly literature in DEA: 1978-2016. SocioEconomic Planning Sciences, 61, 4-8. https://doi.org/10.1016/j.seps.2017.01.008

Griffith R., Harrison R., Van Reenen J. (2006) How Special Is the Special Relationship? Using the Impact of U.S. R\&D on U.K. Firms Spillovers as a Test of Technology Sourcing. American Economic Review, 96, 1859-1875.

Griliches Z. (1958) Research Costs and Social Returns: Hybrid Corn and Related Innovations. Journal of Political Economy, 66 (5), 419-431. https://www.jstor.org/stable/1826669

Griliches Z. (1979) Issues in assessing the contribution of research and development to productivity growth. The Bell Journal of Economics, 10(1): 92-116. https://doi.org/10.2307/3003321.

Hagedoorn J. Duysters G. (2002) External Sources of Innovative Capabilities: The Preferences for Strategic Alliances or Mergers and Acquisitions. Journal of Management Studies, 39, 167-188. https://doi.org/10.1111/1467-6486.00287

Hagedoorn J., Cloodt M. (2003) Measuring innovative performance: Is there an advantage in using multiple indicators? Research Policy, 32(8), 1365-1379. https://doi.org/10.1016/S0048-7333(02)00137-3 
Haleblian J., Devers C.E., McNamara G., Carpenter M.A., Davison R.B. (2009) Taking stock of what we know about mergers and acquisitions: A review and research agenda. Journal of Management, 35(3), 469-502. https://doi. org/10.1177\%2F0149206308330554

Hall B.H. (1996) The private and social returns to research and development (NBER Working Paper No. R2092), Cambridge, MA: National Bureau of Economic Research.

Healy P.M., Palepu K.G., Ruback R.S. (1992) Does corporate performance improve after mergers? Journal of Financial Economics, 31(2), 135-175. https://doi.org/10.1016/0304-405X(92)90002-F

Hitt M., Hoskisson R., Ireland R., Harrison J. (1991) Effects of Acquisitions on R\&D Inputs and Outputs. The Academy of Management Journal, 34(3), 693-706. https://doi.org/10.2307/256412

Hitt M., Hoskisson R., Johnson R., Moesel D. (1996) The Market for Corporate Control and Firm Innovation. The Academy of Management Journal, 39(5), 1084-1119. https://doi.org/10.5465/256993.

Holger E., Vitt J. (2000) The Influence of Corporate Acquisitions on the Behavior of Key Inventors. R\&D Management, 30, 105-120. https://doi.org/10.1111/1467-9310.00162

Hung S.C., Lee Y., Lin B.W. (2006) R\&D intensity and commercialisation orientation effects on financial performance. Journal of Business Research, 59(6), 679-685. https://doi.org/10.1016/j.jbusres.2006.01.002

Iwasa T., Odagiri H. (2004) Overseas R\&D, knowledge sourcing, and patenting: An empirical study of Japanese R\&D investment in the US. Research Policy, 33(5): 807-828. https://doi.org/10.1016/j.respol.2004.01.002

Jemison D., Haspeslagh P. (1991) Managing Acquisitions: Creating Value through Corporate Renewal, New York: Free Press.

Jovanovic B., Rousseau P.L. (2008) Mergers as reallocation. The Review of Economics and Statistics, 90(4), 765-776. https://doi. $\operatorname{org} / 10.1162 /$ rest.90.4.765

King D.R., Slotegraaf R.J., Kesner I. (2008) Performance implications of firm resource interactions in the acquisition of R\&Dintensive firms. Organisation Science, 19(2), 327-340. https://doi.org/10.1287/orsc.1070.0313

Koellinger P. (2008) The relationship between technology, innovation, and firm performance - Empirical evidence from e-business in Europe. Research Policy, 37(8), 1317-1328. https://doi.org/10.1016/j.respol.2008.04.024

Kohers N., Kohers T. (2000) The value creation potential of high-tech mergers. Financial Analysts Journal, 56(3), 40-51. https://doi.org/10.2469/faj.v56.n3.2359

Lane P.J., Lubatkin M. (1998) Relative absorptive capacity and interorganisational learning. Strategic Management Journal, 19: 461-477. https://doi.org/10.1002/(SICI)1097-0266(199805)19:5\%3C461::AID-SMJ953\%3E3.0.CO;2-L

Liu H., Chen T., Pai L. (2007) The Influence of Merger and Acquisition Activities on Corporate Performance in the Taiwanese Telecommunications Industry. The Service Industries Journal, 27(8), 1041-1051. https://doi.org/10.1080/02642060701673729

Lozano S., Villa G. (2010) DEA-based pre-merger planning tool. Journal of the Operational Research Society, 61(10), 14851497. https://doi.org/10.1057/jors.2009.106

Mansfield E. (1988) Industrial R\&D in Japan and the United States: A Comparative Study. The American Economic Review, 78(2): 223-228. https://www.jstor.org/stable/1818127

Ortega-Argilés R., Piva M., Potters L., Vivarelli M. (2010) Is corporate R\&D investment in hightech sectors more effective? Contemporary Economic Policy, 28, 353-365. https://doi.org/10.1111/j.1465-7287.2009.00186.x

Peters R.H., Taylor L.A. (2017) Intangible capital and the investment-q relation. Journal of Financial Economics, 123(2): 251272. https://doi.org/10.1016/j.jfineco.2016.03.011

Peyrache A. (2013) Industry structural inefficiency and potential gains from mergers and break-ups: A comprehensive approach. European Journal of Operational Research, 230(2): 422-430. https://doi.org/10.1016/j.ejor.2013.04.034

Phillips R.L., Ormsby R. (2016) Industry classification schemes: An analysis and review. Journal of Business \& Finance Librarianship, 21(1), 1-25. https://doi.org/10.1080/08963568.2015.1110229

Phillips G.M., Zhdanov A. (2013) R\&D and the Incentives from Merger and Acquisition Activity. The Review of Financial Studies, 26(1): 34-78. https://doi.org/10.1093/rfs/hhs109

Prabhu J.C., Chandy R.K., Ellis M.E. (2005) The Impact of Acquisitions on Innovation: Poison Pill, Placebo, or Tonic? Journal of Marketing, 69(1), 114-130. https://journals.sagepub.com/doi/10.1509/jmkg.69.1.114.55514\#

Ranft A., Lord M. (2002) Acquiring New Technologies and Capabilities: A Grounded Model of Acquisition Implementation. Organisation Science, 13(4), 420-441. https://www.jstor.org/stable/3085975 
Ranft A.L., Lord M.D. (2000) Acquiring new knowledge: The role of retaining human capital in acquisitions of high-tech firms. The Journal of High Technology Management Research, 11(2): 295-319. https://doi.org/10.1016/S1047-8310(00)00034-1

Ravenscraft D., Scherer F.M. (1982) The lag structure of returns to research and development. Applied Economics, 14 (6), 603-620. https://doi.org/10.1080/00036848200000036

Ravenscraft D., Scherer F. (1987) Life After Takeover. The Journal of Industrial Economics, 36(2): 147-156. https://doi. org/10.2307/2098409

Sirmon D.G., Hitt M.A., Ireland R.D., Gilbert B.A. (2011) Resource Orchestration to Create Competitive Advantage: Breadth, Depth, and Life Cycle Effects. Journal of Management, 37(5), 1390-1412. https://doi.org/10.1177\%2F0149206310385695

Stoneman P., Kwon M.J. (1996) Technology adoption and firm profitability. The Economic Journal, 106(437), 952-962. https:// doi.org/10.2307/2235366

Wagner M. (2011) To explore or to exploit? An empirical investigation of acquisitions by large incumbents. Research Policy, 40(9): 1217-1225. https://doi.org/10.1016/j.respol.2011.07.006

Wanke P., Maredza A., Gupta R. (2017) Merger and acquisitions in South African banking: A network DEA model. Research in International Business and Finance, 41, 362-376. https://doi.org/10.1016/j.ribaf.2017.04.055

Worthington A.C. (2001) Efficiency in pre-merger and post-merger non-bank financial institutions. Managerial and Decision Economics, 22, 439-452. https://doi.org/10.1002/mde.1033

Xie E., Reddy K.S., Liang J. (2017) Country-specific determinants of cross-border mergers and acquisitions: A comprehensive review and future research directions. Journal of World Business, 52(2), 127-183. https://doi.org/10.1016/j.jwb.2016.12.005 